\title{
Determinants of Bursa Malaysia Stock Market Returns amid the Fourteenth General Election
}

\author{
Venus Khim-Sen Liew ${ }^{1}$, Racquel Rowland ${ }^{2}$ \\ ${ }^{1,2}$ Faculty of Economics and Business, Universiti Malaysia Sarawak, 94300 Kota Samarahan, Sarawak, Malaysia \\ ${ }^{1}$ E-mail: ksliew@unimas.my (Corresponding author), ${ }^{2} E$-mail: rac_0524@hotmail.my
}

\begin{abstract}
This study attempts to examine the effect of the Fourteenth General Election on the market returns in Malaysia. It is found that the election effect lasted for 30 days of trading window and the stock market managed to price-in the election news since then. Secondly, market volatility which represents political uncertainty continued to play significant role in determining stock market return, as were in the previous two general elections. Nonetheless, market volatility had adverse effect, and as such Bursa Malaysia might not fulfil the appetite of those investors who demand higher return for higher risks amid election year. In addition, this study for the first time reveals fairly low but significant market integration between Malaysia and US stock market around the general election year. This signifies that apart from domestic political issues and macroeconomic performances amid general election event, investors in Bursa Malaysia need to closely monitor global issues that would affect the US stock market and hence the performance of Bursa Malaysia.

Key words Stock Market, Bursa Malaysia, General Election Effect, KLCl, S\&P500

$\begin{array}{lll}\text { Received: } & 04 \text { Jul } 2020 \quad \text { C The Authors } 2020 \\ \text { Revised: } & 18 \text { Aug } 2020 \quad \text { Published by Human Resource Management Academic Research Society (www.hrmars.com) }\end{array}$

Accepted: 12 Sep 2020 This article is published under the Creative Commons Attribution (CC BY 4.0) license. Anyone may Published Online: 29 Sep 2020 reproduce, distribute, translate and create derivative works of this article (for both commercial and non-commercial purposes), subject to full attribution to the original publication and authors. The full terms of this license may be seen at: http://creativecommons.org/licences/by/4.0/legalcode
\end{abstract}

\section{Introduction}

Numerous studies had documented significant general election (GE) effect on stock market behaviour in Malaysia (Ong et al., 2015; Lean \& Yeap, 2016; Liew \& Rowland, 2016; Tay et al., 2016; Ricky, 2018). Notably, based on event study methodology to analysis data over the 2004 to 2013 period, Tay et al. (2016) demonstrate that the Malaysia stock market had gained significant cumulative abnormal returns 15 days before and 15 days after general elections ${ }^{1}$. In a separate attempt using more extensive data set spanning from 1995 to 2013, Liew \& Rowland (2016) adopt regression analysis to show that out of the five general elections under studied, $40 \%$ of the time the stock market reacted positively before the elections, whereas $60 \%$ of the time the market reacted positively after the elections ${ }^{2}$. These implied that the stock market in Malaysia meticulously follows the consequences and deliberations of general election. Nonetheless, the coverage of these studies was up to the Thirteenth General Election (GE13) held in 2013. Moreover, Liew and Rowland (2016) reveal that general election effect in Malaysia varied in degree from

\footnotetext{
1 The study covers three general elections in Malaysia: The Eleventh (2004), Twelfth (2008) and Thirteenth (2013) General Elections.

${ }^{2}$ It covers the Ninth (1995), Tenth (1999), Eleventh (2004), Twelfth (2008) and Thirteenth (2013) General Elections in Malaysia.
} 
one general election to another. In this respect, the current study attempts to update the literature with the most recent episode of general election, the Fourteenth Malaysia General Election (GE14).

GE14, held on $9^{\text {th }}$ May 2018, was the most anticipated political events by market participants. Prior to this, Malaysia was known for its one-party rule practice for the past 60 years of independence. In the Thirteenth General Election (GE13) held on $5^{\text {th }}$ May, 2013, there was a close battle between the two political parties. However, the incumbent Barisan Nasional (BN, The National Alliance) coalition succeeded to return to office after securing 135 out of 222 parliament seats, while Pakatan Rakyat (PR, The People's Alliance) managed to sweep 89 seats. However, it was a surprise turnover when Pakatan Harapan ( $\mathrm{PH}, \mathrm{The}$ Alliance of Hope) coalition for the first time broke the curse and dominated 125 out of a total of 222 parliament seats in GE14 ${ }^{3}$.

\section{Movement of FTSE Bursa Malaysia $\mathrm{KLCl}$ around GE14 period}

The overall performance of Bursa Malaysia can be traced by the FTSE Bursa Malaysia KLCI Index Kuala Lumpur Composite Index, or in short, $F B M K L C I . F B M K L C l$ was launched, on July 6, 2009 to replace the Bursa Malaysia $K L C l$ Index. Inherent from its predecessor, it comprises of the largest 30 companies by full market capitalization on Bursa Malaysia's Main Board. Figure 1 shows its daily movement over the period ranging from January 2018 - October 2019. It can be seen from Figure 1 that as the election approached, that the index gradually increased from 1782.7 (January 2, 2018) to 1895.18 (April 19, 2018), few months prior to the election date, as investors were optimistic and confidence that the election was going to be dominated by BN coalition again. The index closed at 1846.51 points during the election eve (May 8,2018 ). After the election was over, the index fell to 1797.14 points during the intraday of the next trading day (May 14, 2018) but it managed to close at 1850.42 , with a slight positive return ${ }^{4}$. Nevertheless, the index was in general pointing to the south since then for a prolong period, as indicated in Figures 1 and 2 .

Figure 1. Daily Movement of FBMKLCI from January 2018 - October 2019

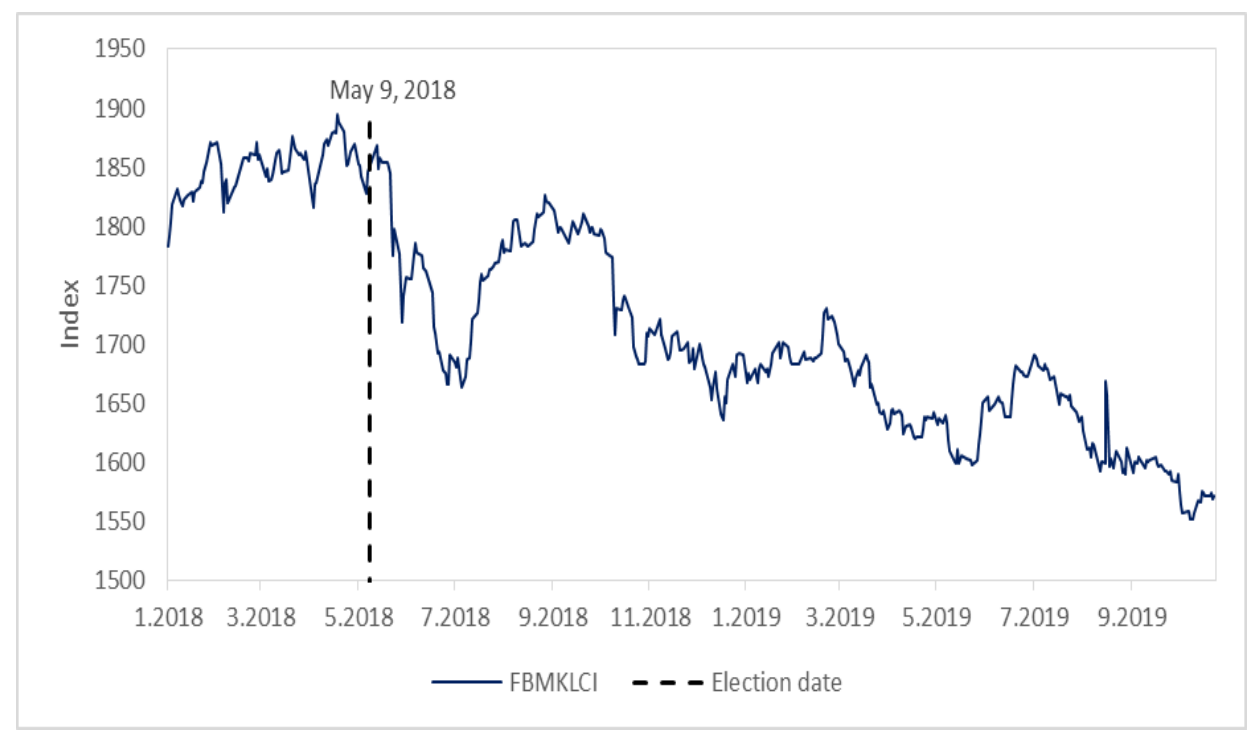

Source: The daily data set was obtained from Bursa Malaysia (2019).

Figure 2 shows the weekly movement of FBMKLCl over from January 2016 to December 2019. It is evident that overall, the index rose gradually from 1692.51 in the first week of 2016 to 1887.75 three weeks before the GE14. However, after the GE14, the index was fluctuating along a downward trend and it ended up at 1610.61 (which is lower than the level at the beginning of 2016) during the closing week of

\footnotetext{
${ }^{3}$ Mahathir bin Mohamad sworn in as the $7^{\text {th }}$ Prime Minister of Malaysia on May2018. He resigned on 24 $4^{\text {th }}$ February, 2020. On 29th February, 2020, Muhyiddin bin Haji Muhammad Yassinwas appointed as the $8^{\text {th }}$ Prime Minister of Malaysia. The new coalition government led by him is known as the National Alliance (PN, Perikatan Nasional).

${ }^{4}$ May 10 (Thursday) and May 11, 2019 (Friday) were declared by the then new government as public holidays to celebrate the historical political development in Malaysia.
} 
2019. The negative reaction in the market at the beginning of the post-GE14 period could be due to market fear resulting from the newly elected PH coalition which had no experience in governing the country amid the transition of political power in Malaysia for the first time, except the leader himself. The further prolong decline in the index could be the consequences of political uncertainty surrounding the PH member parties and the continuous market disappointment over the non-satisfactory delivery of the PH's GE14 Manifesto and sluggish economic performance of the country.

Figure 2. Weekly Movement of FBMKLCl, January 2016 - December 2019

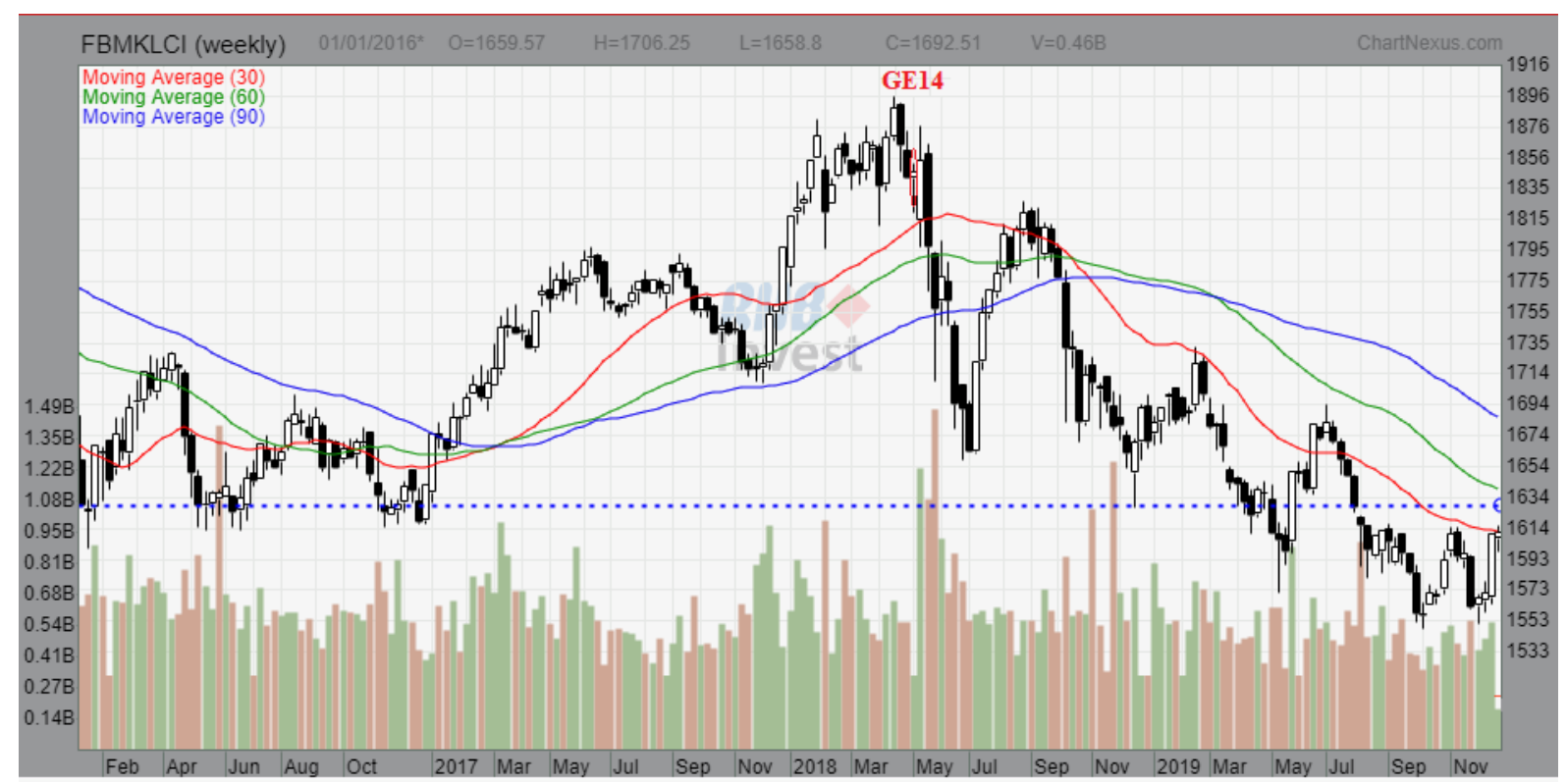

Source: Snapshot from the desktop terminal of author who holds an investing account at the RHB Investment Bank Limited, Malaysia.

\section{Methodology of research}

This study employs daily closing price of the FTSE Bursa Malaysia Kuala Lumpur Composite Index $(F B M K L C I)$, US stock market (S\&P500), and market volatility (MV) which represents political uncertainty. A set of macroeconomic variables namely inflation rate (INF), unemployment rate (UNEMPLOY), interest rate (INT), exchange rate (EXR) and gross domestic product growth rate (GDP) are also included in the analysis. There were a total of 280 observations for each variable retrieved from CEIC and Bank Negara Malaysia. In the vein of Liew and Rowland (2016), the daily FBMKLCl data set ranging from September 2017 to September 2018 is set to cover the most recent election, that is GE14. The recent election was conducted on $9^{\text {th }}$ May 2018 and this date set by the Electoral Commission of Malaysia is treated as the event date in the study.

The daily stock return is computed as follows:

$$
R_{i t}=100 \times\left[\ln \left(I_{i t}\right)-\ln \left(I_{i t-1}\right)\right]
$$

Where $I_{i t}$ and $I_{i t-1}$ are stock indices, that is, FBMKLCl or S\&P500 at time $t$ and $t-1$ respectively and $I n$ represents natural logarithm. Since this study utilizes two different stock market indices, $F B M K L C I$ and $S \& P 500$, it is important to recognize national holidays for respective markets and consider only trading days on which both markets are open. Also, these markets operate at different time zones such that the previous day is taken as day $t$ for $S \& P 500^{5}$.

Based on Opare's (2012) approach, the market volatility is estimated as:

\footnotetext{
${ }^{5}$ Malaysia's time is 8 hours ahead of US, such that the day $t-1$ of US stock market closes in the morning of day $t$ for Malaysia. Put in other words the most recent US stock market data available to today's Bursa Malaysia investors are the yesterday's closing prices of US stocks.
} 
$V O L_{t}=100 \times\left[\ln \left(H_{t}\right)-\ln \left(L_{t}\right)\right]$

Where ${ }^{H_{t}}$ and ${ }^{L_{t}}$ denote the highest and lowest value of $F B M K L C l$ at time $t$.

Following Liew and Rowland (2016), this study estimates the following ordinary least squares (OLS) model by regressing returns from $R F B M K L C l\left(R_{t}\right)$ on a set of macroeconomic variables with the inclusion of election dummy variables:

$$
\begin{gathered}
\text { RFBMKLCI }=\beta_{0}+\beta_{1} B_{t}+\beta_{2} A_{t}+\beta_{3} R S \& P 500_{t}+\beta_{4} I N F_{t}+\beta_{5} E X R_{t}+\beta_{6} G D P G R_{t}+ \\
\beta_{7} I N T_{t}+\beta_{8} U N E M P L O Y_{t}+\beta_{9} M V_{t}+\varepsilon_{t}
\end{gathered}
$$

for $N=15,30,60$ and 90 days

Where ${ }^{B_{t}}=$ before-election dummy variable that equals to one for $N$ trading days before election and zero otherwise. $A_{t}=$ after-election dummy that equals to one for $N$ trading days after election and zero otherwise. $R S \& P 500_{t}=$ daily return of S\&P500 in percentage; $I N F_{t}=$ percentage change in world crude oil price; $E X R_{t}=$ Malaysia ringgit per US dollar rate; $G D P G R_{t}=$ percentage change in quarterly Gross Domestic Product; ${ }^{I N T_{t}}=$ Malaysian daily average interbank deposit rate; ${ }^{U N E M P L O Y_{t}}=$ monthly rate of unemployment as the daily rate is unavailable; ${ }^{M V_{t}}=$ Malaysia stock market volatility; and ${ }^{\varepsilon_{t}}=$ error term.

The equation is estimated for four different trading windows $(30,60$ and 90$)$ to observe the general election effect on the returns of $F B M K L C l$ at different timeframe. When the coefficient of ${ }^{\beta_{1}}$ is significant, then there is a significance effect on the daily returns before the event. Similarly, when the coefficient of $\beta_{2}$ is significant, then there is a significance effect on the daily returns after the event. However, if none of them is statistically significant, it means that the news has been incorporated into the stock price and stock market is not affected by the general election.

\section{Results of Analysis}

Table 1 presents the summary statistics on the different variables considered in this study. The sample period is spanning from September 2017 to September 2018. According to the summary, the sample mean returns from $F B M K L C l$ and S\&P500 were relatively small. They were $0.01 \%$ and $0.06 \%$ respectively with relatively large sample standard deviation $(0.60 \%$ and $0.78 \%)$. In fact, market volatility which is a measure of political uncertainty was peaked at $4.33 \%$ during the election month (results not shown here). This makes sense as Malaysia experienced its first ever political transition in history and hence, it induced market uncertainty. Notably, gross domestic product (measured in percentage change) was the most volatile macroeconomic variable with a sample standard deviation of $2.98 \%$. This high volatility index in gross domestic product could be the consequence of a change in goods and services tax policy by the new government, in which GST was replaced with SST effective from September 1, 2018. The Jarque-Bera $(J-B)$ normality test results suggest that all variables were non-normally distributed.

Since the data employed possessed non-normality feature, Kendall Tau- $b$ (rather than the Pearson) correlation analysis with bootstrapping approach is conducted to determine the degree of association among the variables. Table 2 provides the estimated correlation coefficients among the variables. A key finding is that a significant correlation between returns of $F B M K L C I$ and $S \& P 500$ was established. Specifically, a coefficient of 0.23 between $R F B M K L C l$ and $R S \& P 500$ indicates a positive correlation but a fairly low degree of market integration in both countries. Moreover, this correlation is significant at $1 \%$ level.

Table 3 presents result of OLS regression analysis for three different window lengths $(30,60$ and 90 days) to observe the general election effect on the returns of $F B M K L C l$ at different event window. Bootstrapped $p$-value was estimated to overcome the problem of the econometric issue of non-normal and heteroscedasticity in the residuals of the estimated model. Overall, it is noteworthy that US stock market, the leading and influential market in the world, had positive and significant effect ( $1 \%$ significant level) on 
Malaysia stock market across all event windows. It is observed that, on average, a $1 \%$ change in the S\&P500 daily return could be associated to $0.30 \%$ change in the $F B M K L C l$ daily return, in the same direction. This finding is consistent with the earlier finding of fairly low degree of stock market integration between these two countries by the correlation analysis. Nonetheless, it is in contrast with Liew and Rowland (2016) that report no relationship between Malaysia and US stock markets for all the previous five episodes of general election. On the main focus of this study, it is evident that the GE14 is statistically associated to negative daily returns for 30 days before and after election. The estimated for $\beta_{1}$ and $\beta_{2}$ are -0.27 and -0.41 respectively and they are all statistically significant at least at $10 \%$ significance level for $N=30$. This explained that during the 30 trading days before GE14, the average market return had been reduced by $0.27 \%$ (marginally significant at $10 \%$ ) per trading day and it was further reduced by $0.41 \%$ (significant at $5 \%$ ) per trading day during the 30 days after GE14 compared to ordinary trading days. ${ }^{6}$

Table 1. Summary of Statistics, September 2017 to September 2018

\begin{tabular}{lcccccccc}
\hline & RFBMKLCI & RS\&P500 & INF & EXR & GDPGR & INT & UNEMPLOY & MV \\
\hline Mean & 0.01 & 0.06 & 7.41 & 4.07 & 1.84 & 3.09 & 3.36 & 0.63 \\
Median & 0.04 & 0.07 & 7.37 & 4.07 & 3.72 & 3.16 & 3.40 & 0.52 \\
Maximum & 1.54 & 2.78 & 9.13 & 4.30 & 3.96 & 3.25 & 3.50 & 4.33 \\
Minimum & -3.24 & -4.41 & 5.56 & 3.86 & -3.68 & 2.90 & 3.30 & 0.17 \\
Std. Dev. & 0.60 & 0.78 & 1.01 & 0.13 & 2.98 & 0.13 & 0.06 & 0.46 \\
J-B test & 320.91* & $561.78^{*}$ & $17.80^{*}$ & $18.85^{*}$ & $64.19^{*}$ & $33.47^{*}$ & $13.20^{*}$ & $4500.49 *$ \\
\hline
\end{tabular}

Notes: RFBMKLCl and RS\&P500 refer to the returns of FTSE Bursa Malaysia Kuala Lumpur Composite Index and $S \& P 500$, market volatility (VOL) which represents political uncertainty, and a set of macroeconomic variables namely exchange rate (EXR), percentage change in gross domestic product (GDPGR), inflation rate (INF), interest rate (INT) and unemployment rate (UNEMPLOY). Asterisk $\left({ }^{*}\right)$ shows that the null hypothesis of normally distribution is statistically rejected at $1 \%$ significance level, based on Jarque-Bera $(J-B)$ test.

Table 2. Kendall Tau-b Correlation Analysis Results, September 2017 to September 2018

\begin{tabular}{ccccccccc}
\hline & RFBMKLCI & RS\&P500 & INF & EXR & GDPGR & INT & UNEMPLOY & MV \\
\hline RFBMKLCI & 1.00 & & & & & & & \\
RS\&P500 & - & $0.23^{*}$ & 1.00 & & & & & \\
& {$[0.00]$} & - & & & & & \\
INF & 0.02 & 0.00 & 1.00 & & & & \\
& {$[0.66]$} & {$[0.95]$} & - & & & & \\
EXRE & -0.04 & 0.00 & $-0.32^{*}$ & 1.00 & & & \\
& {$[0.28]$} & {$[1.00]$} & {$[0.00]$} & - & & & \\
GDPGR & 0.04 & 0.04 & -0.01 & $0.51^{*}$ & 1.00 & & \\
& {$[0.35]$} & {$[0.41]$} & {$[0.80]$} & {$[0.00]$} & - & & & \\
INT & 0.08 & 0.00 & $0.48^{*}$ & $-0.28^{*}$ & 0.04 & 1.00 & & \\
& {$[0.05]$} & {$[0.98]$} & {$[0.00]$} & {$[0.00]$} & {$[0.44]$} & - & & \\
UNEMPLOY & 0.04 & 0.07 & $-0.18^{*}$ & $0.39^{*}$ & $0.34^{*}$ & $-0.13^{*}$ & 1.00 & - \\
& {$[0.44]$} & {$[0.16]$} & {$[0.00]$} & {$[0.00]$} & {$[0.00]$} & {$[0.01]$} & $-0.17^{*}$ & 1.00 \\
MV & -0.01 & $-0.07^{*}$ & $0.35^{*}$ & $-0.31^{*}$ & $-0.12^{*}$ & $0.22^{*}$ & $-0.00]$ & - \\
\hline
\end{tabular}

Note: The bootstrapped $p$-values (obtained based on 100,000 replicated samples) of the correlation coefficients are given in square parentheses. Asterisk $\left({ }^{*}\right)$ shows statistical significant at $1 \%$ significance level.

Significant GE14 effect is not found for other timeframes. It reveals that beyond 30 days, GE14 effect was already priced in and therefore market returns were solely determined by other variables. In this respect, it is observed that gross domestic product growth rate had significant impact on the market returns for $N=30$ only, whereas interest rate had significantly affected the market returns for $N=60$ only. On the contrary, exchange rate possesses a negative and significant impact on the market return for $N=30$

\footnotetext{
${ }^{6}$ The parliament was dissolved on April 7, 2018 to give way to the GE14.
} 
and 60-day trading windows. The results are statistically significant for at least $10 \%$ significance level. This finding is in line with Ong et al. (2015) which document the significant role of currency on stock returns in Malaysia.

Table 3. Estimated Regression Results Across Various Event Windows

\begin{tabular}{|c|c|c|c|c|c|c|}
\hline \multirow{3}{*}{ Variable } & \multicolumn{6}{|c|}{ Window Length (Day) } \\
\hline & 30 & & 60 & & 90 & \\
\hline & Est. & $p$ & Est. & $p$ & Est. & $p$ \\
\hline Constant & 3.10 & {$[0.39]$} & 2.05 & {$[0.61]$} & -4.66 & {$[0.38]$} \\
\hline Before & -0.27 & {$[0.10]^{\#}$} & -0.25 & {$[0.19]$} & 0.18 & {$[0.46]$} \\
\hline After & -0.41 & {$[0.03]^{\&}$} & -0.14 & {$[0.27]$} & -0.13 & {$[0.72]$} \\
\hline$S \& P 500$ & 0.29 & {$[0.00]^{*}$} & 0.29 & {$[0.00]^{*}$} & 0.30 & {$[0.00]^{*}$} \\
\hline Inflation Rate & -0.09 & {$[0.16]$} & -0.11 & {$[0.22]$} & 0.02 & {$[0.86]$} \\
\hline Exchange Rate & -1.79 & {$[0.02]^{\&}$} & -1.46 & {$[0.06]^{\#}$} & -0.25 & {$[0.73]$} \\
\hline GDP Growth Rate & 0.05 & {$[0.08]^{\#}$} & 0.03 & {$[0.26]$} & 0.03 & {$[0.24]$} \\
\hline Interest Rate & 0.53 & {$[0.15]$} & 0.91 & {$[0.10]^{\#}$} & 0.56 & {$[0.22]$} \\
\hline Unemployment Rate & 0.98 & {$[0.13]$} & 0.62 & {$[0.48]$} & 1.14 & {$[0.16]$} \\
\hline Market Volatility & -0.18 & {$[0.38]$} & -0.27 & {$[0.18]$} & -0.24 & {$[0.25]$} \\
\hline$R$-Square & 0.23 & & 0.20 & & 0.21 & \\
\hline$F$ & 8.99 & & 7.72 & & 7.77 & \\
\hline Normality ${ }^{a}$ & $65.76^{*}$ & & $65.37^{*}$ & & $63.00^{*}$ & \\
\hline Heteroscedasticity ${ }^{b}$ & $33.13^{*}$ & & $36.11^{*}$ & & $36.56^{*}$ & \\
\hline Serial correlation $^{c}$ & 1.78 & & 0.3 & & 0.58 & \\
\hline
\end{tabular}

Notes: Estimated based on Equation (3). Symbols (\#, \& and ${ }^{*}$ ) show statistical significant at 10,5 and $1 \%$ significance level respectively. ${ }^{a}$ Jarque-Bera test; ${ }^{b}$ Breusch-Pagan-Godfrey Heteroscedascity test; ${ }^{c}$ Breusch-Godfrey Serial Correlation LM test. Est. means ordinary least square estimate, whereas $p$ refers to bootstrapped $p$-value obtained from 10,000 replications.

While the GE14 effect itself was priced in within 30 days before and 30 days after the event day, stock market returns around the GE14 were nevertheless always related to political risk for all event windows. Such political risk could be due to changes in economic policies by the new government and also due to the unstable government resulting from the conflicting political interest of various $\mathrm{PH}$ coalition parties. In this regards, it is found that stock market returns correlated significantly with market volatility as an indication of political uncertainty. Such finding is consistent with the observations of Liew and Rowland (2016) and Chia (2018) on the previous episodes of general election. The negative coefficients obtained in this study suggest that market returns were significantly reduced by $0.18,0.27$ and $0.24 \%$ for $N=30,60$ and 90 trading days respectively. These results are at least significant at $5 \%$ significance level. Such observation implies that a $1 \%$ increase (decrease) in market volatility, could be associated to a drop (rise) in market returns by 0.18 to $0.27 \%$ during the GE14 period as compared to normal trading days with no election. Previously, negative impact of market volatility for GE12 and GE13 election years was also documented in Liew \& Rowland (2016).

\section{Conclusions}

Numerous studies had shown that general election (GE) had significant effect on stock market behaviour in Malaysia for the Thirteenth General Election and episodes before it. Remarkably, Liew \& Rowland (2016) reveal that general election effect in Malaysia varied in degree for Ninth General Election of 1995 to Thirteenth General Election of 2013. To this extend, the current study attempts to examine the effect of the most recent episode of general election that is the Fourteenth General Election of 2018 on the market returns in Malaysia. Several major conclusions could be drawn from the current study. Firstly, it is found that this time around, the election effect lasted for 30 days of trading window length and the stock market managed to price in the information since then. Notably, the stock market daily returns, on average, had been reduced by as much as $0.27 \%$ during the 30 days before GE14 and $0.41 \%$ during the 30 days after GE14 in 2018, compared to normal trading days. 
Secondly, it is noteworthy that market volatility which represents political uncertainty continued to play significant role in determining stock market return in the last general election of 2018. Previously, it had been found significant in the Twelfth General Election of 2008, and the Thirteenth General Election of 2013 (Liew \& Rowland, 2016). Thus, while the GE14 was over and its effect itself was priced in within 30 days before and 30 days after the event day, stock market returns were nevertheless always related to continuous political risk generated around the GE14 event, for all events window lengths.

This time, such political risk could be due to changes in economic policies by the new government and also due to the unstable government resulting from the conflicting political interest of various $\mathrm{PH}$ coalition parties. In this regards, it is unsurprising to find that stock market returns correlated significantly with market volatility as an indication of political uncertainty around the last general election year. Moreover, it is found that a $1 \%$ increase (decrease) in market volatility, could be associated to a drop (rise) in market returns by 0.18 to $0.27 \%$ during the GE14 as compared to normal trading days with no election. Nevertheless, while it is established that market volatility was higher during election year, this finding of adverse effect suggests that the higher market risk was compensated with lower investment returns in Bursa Malaysia amid the GE14. Thus, the market might not fulfil the appetite of those investors who demand higher return for higher risk during general election times.

Lastly but not least, this study reveals a fairly low but significant market integration between Malaysia and US stock market. This signifies that apart from domestic political issues and macroeconomic performances, investors in Bursa Malaysia need to keep their eyes on the global political and economic issues that would affect the US stock market and hence the performance of Bursa Malaysia. For future research undertaking, the recent novel coronavirus (COVID-19) pandemic which has been shown to affect Bursa Malaysia (Chia et al., 2020 and Lee et al., 2020) significantly, may also be considered as a potential determinant of stock market return amid the next general election of Malaysia, in case it so happens to be any sooner.

\section{References}

1. Bursa Malaysia. (2019). Historical Data Packages. Available at: https://www.bursamalaysia.com/ market_information/market_data/historical_data_packages.

2. Chia, R. C. J. (2018) "The Effect of Political Elections on Stock Market Volatility in Malaysia". International Journal of Engineering and Technology 7, 114-119.

3. Chia, R. C. J., Liew, V. K. S., and Rowland, R. (2020) "Daily New Covid-19 Cases, the Movement Control Order, and Malaysian Stock Market Returns", International Journal of Business and Society 21 (2), 553-568.

4. Lean, H. H., and Yeap, G. P. (2016) "Asymmetric Effect of Political Elections on the Stock Return and Volatility in Malaysia" In Information Efficiency and Anomalies in Asian Equity Markets: Theories and Evidence by Munir, Q and S. C. Kok Eds., Routledge, 228-245.

5. Lee, K. Y. M., Mohamad, J., \& Chan, C. W. (2020) "Impact of Covid-19: Evidence from Malaysian Stock Market" International Journal of Business and Society 21 (2), $607-628$.

6. Liew, V. K. S., and Rowland, R. (2016) "The Effect of Malaysia General Election on Stock Market Returns" SpringerPlus 5, 1 - 13.

7. Ong, T. S., Soh, W. N., The, B. H., and Ng, S. H. (2015) "Stock Return, Currency and General Elections" Pertanika Journal Social Science and Humanities 23, 237-250.

8. Tay, L. Y., Rasiah, D., and Lai, M. M. (2016) "Behaviour of Stock Returns in Relation to General Elections. Evidence from Malaysian Stock Market" Information 19, 2955-2959. 